\title{
Aos pés da virgem azul: notas sobre simbolismo, sincretismo religioso e tradição no paraguai
}

\section{At the feet of the blue virgin: notes on symbolism, religious syncretism and tradition in paraguay}

\section{A los pies de la Virgen Azul: notas sobre el simbolismo, el sincretismo religioso y la tradición en Paraguay}

\author{
Valdir Aragão do Nascimento \\ ${ }^{a}$ Doutor em Saúde e Desenvolvimento na Região Centro-Oeste PPGSD/UFMS. Mestre em Antropologia pelo PPGAnt/UFGD. \\ E-mail: 33valdir@gmail.com
}

Resumo: O presente artigo objetiva analisar, de maneira sucinta, alguns aspectos da religiosidade paraguaia, tais como o sincretismo e sua relação com as tradições e a identidade nacional. Busca-se, aqui, identificar as interfaces existentes entre religiosidade, sincretismo religioso, identidade nacional e tradição na cultura paraguaia. A metodologia utilizada é a revisão bibliográfica e o trabalho de campo de caráter etnográfico. Constata-se que a religiosidade no Paraguai tem um viés sincrético, mas ainda inconfessado. Verifica-se também que a identidade nacional do povo paraguaio é tributária de tradições culturais herdadas tanto de sua matriz indígena quanto das contribuições do colonizador europeu. Desse modo, a identidade nacional e religiosa do povo paraguaio pode ser localizada tanto no seu devir histórico enquanto nação quanto nas manifestações culturais acionadas para representar tais identidades.

Palavras-chave: Simbolismo; Sincretismo Religioso; Identidade Nacional; Tradições; Paraguai.

\begin{abstract}
This article aims to analyze, briefly, some aspects of the Paraguayan religiosity, such as syncretism and its relationship with the traditions and national identity. It sought up here identify the interfaces between religion, religious syncretism, national identity and tradition in the Paraguayan culture. The methodology used was a bibliographical review and fieldwork of ethnographic character. It was found that religiosity in Paraguay has a syncretic bias but still unacknowledged. It was also found that national identity of the Paraguayan people's tax of inherited cultural traditions of both their indigenous source as the contributions of the European colonizer. Thus, national and religious identity of the Paraguayan people can be located both in its historical development as a nation, as in cultural events triggered to represent such identities.
\end{abstract}

Keywords: Symbolism; Religious Syncretism; National Identity; Traditions; Paraguay.

Como citar o artigo: NASCIMENTO, V.A. Aos pés da virgem azul: notas sobre simbolismo, sincretismo religioso e tradição no paraguai Revista de Ciências Humanas, Florianópolis, v. 542020 DOI: 10.5007/2178-4582.2020. e63235 você pode compartilhar, adaptar, para qualquer fim, desde que atribua a autoria da obra, forneça um link para a licença, e indicar se foram feitas alterações. 
Resumen: Este artículo tiene como objetivo analizar, de manera sucinta, algunos aspectos de la religiosidad paraguaya, como el sincretismo y su relación con las tradiciones y la identidad nacional. Aquí, buscamos identificar las interfaces existentes entre religiosidad, sincretismo religioso, identidad nacional y tradición en la cultura paraguaya. La metodología utilizada es una revisión bibliográfica y trabajo de campo etnográfico. Parece que la religiosidad en Paraguay tiene un sesgo sincrético, pero aún no se reconoce. También se observa que la identidad nacional del pueblo paraguayo es el resultado de tradiciones culturales heredadas tanto de su matriz indígena como de los aportes del colonizador europeo. De esta manera, la identidad nacional y religiosa del pueblo paraguayo puede ubicarse tanto en su desarrollo histórico como nación como en las manifestaciones culturales que se desencadenan para representar tales identidades.

Palabras clave: Simbolismo; Sincretismo religioso; Identidad nacional; Tradiciones; Paraguay.

\section{INTRODUÇÃO}

O fenômeno religioso constitui-se tema há muito estudado por pesquisadores de várias áreas do conhecimento, notadamente aquelas voltadas para a compreensão da conformação sociocultural das sociedades e suas culturas. Na sociologia, destacam-se Marx (1975), Durkheim (1989), Weber (1989) e Bourdieu (1976), dentre outros, cujos esforços teóricos sempre tiveram o cuidado de tecer possibilidades de interpretação de diversos aspectos da vida religiosa e sua influência nas sociedades humanas.

$\mathrm{Na}$ antropologia, várias foram as contribuições ao estudo dos fenômenos culturais relativos às crenças religiosas, tendo como expoentes Tylor (1976), Evans-Pritchard (1956; 2005), Lévi-Strauss (1989), Frazer (1890), Geertz (1989), Malinowski (1988), para citar alguns. No que tange às concepções antropológicas (especificamente às de orientação simbólica/hermenêutica/interpretativa) a respeito dos pressupostos ontológicos da categoria religião, esta pode ser definida como um complexo conjunto de símbolos que age no sentido de instituir "poderosas, penetrantes e duradouras disposições e motivações nos homens através da formulação de conceitos de uma ordem de existência geral e vestindo essas concepções com tal aura de fatualidade que as disposições e motivações parecem singularmente realistas". A representação de símbolo que aqui se emprega é aquela de "objeto, ato, acontecimento, qualidade ou relação que serve como veículo a uma concepção - a concepção é o significado do símbolo" (GEERTZ, 1989, p. 67).

A religião, assim pensada, constitui uma das ferramentas simbólicas estruturantes da consciência humana, tanto que "nos mais arcaicos níveis de cultura, viver como ser humano é em si um ato religioso, pois a alimentação, a vida sexual e o trabalho têm um valor sacramental. Em outras palavras, ser - ou, antes, tornar-se - um homem significa ser "religioso"' (ELIADE, 2010, p. 13, grifo do autor). É, nessa perspectiva, um fato social total (MAUSS, 1988), dadas as influências e o impacto que causa em praticamente todos os aspectos da vida sociocultural de inúmeros povos ao redor do mundo.

Os símbolos aos quais se refere Geertz $(1989$, p. 69) são, para ele, instrumentos de conexão entre o mundo abstrato e o mundo empírico, tendo sua cisão somente na esfera teórica, "a dimensão simbólica dos acontecimentos sociais é, como a psicológica, ela mesma abstraível a partir desses acontecimentos como totalidades empíricas". Nesse sentido, os símbolos podem ser entendidos como portadores e veículos da cultura, não se limitando às representações imagéticas de um dado objeto, mas amalgamando em si todas as representações que se lhes atribui um agrupamento coletivo social e culturalmente organizado.

Mas os símbolos e suas significações não são fixos e inamovíveis, portanto, transitam entre as culturas tanto sincrônica como diacronicamente, imiscuindo-se na realidade sociocultural e psicológica dos povos e representando suas necessidades de expressão e comunicação. Ilustra a assertiva a transformação do símbolo da suástica em um símbolo nazista. A suástica, que em sânscrito antigo quer dizer "bem-estar", foi durante milênios utilizada por hindus, budistas e jainistas como símbolo religioso (CHEVALIER; GHEERBRANT, 2002).

Em verdade, não se sabe ao certo qual foi o povo, e em que época da história da humanidade se começou a usar o símbolo da suástica, nem tampouco os diversos sentidos que podem lhe ter sido 
atribuídos, todavia é inegável sua longevidade e variedade de funções, tendo sido registrada sua presença em achados arqueológicos "pelo menos, desde os finais do VI milénio a.C.,", e atualmente ainda é "utilizado com caráter simbólico-religioso no Oriente, estando também presente na etnografia ocidental, geralmente com valor decorativo, exceto alguns casos em que ainda revela um certo caráter de proteção." (MARTINS; COIMBRA, 1997, p. 5).

A circulação de símbolos e seus sentidos pelos tecidos sociais contribui sobremaneira para a conformação da religiosidade e da identidade nacional de um povo. Mas os símbolos escapam de suas amarras conceituais e se transformam em outras coisas, gerando outros sentidos ou agregando aos já existentes elementos com outras significações. Não obstante, essas ressignificações não constituem, a rigor, sincretismo no sentido estrito do termo; mas atendem, em maior ou menor grau, às necessidades socioculturais de povos em contato. Ainda que não possam ser considerados como fenômenos sincréticos em si mesmos, o deslocamento de símbolos, sentidos e ressignificações perpassam a história de várias culturas em todo o mundo, sendo melhor percebido nas manifestações religiosas.

Em que pese o fato de que a adoção de determinados significantes não implicar necessariamente na combinação de significados sob a forma de um ente sincrético, a categoria sincretismo aqui utilizada pode ser entendida como uma noção particular da qual o autor se serve na tentativa de compreensão do fenômeno religioso no Paraguai, notadamente no que tange ao trânsito de signos, sentidos e significados simbólicos (e suas ressignificações) no contexto sociocultural ${ }^{1}$. Não se quer dizer, a partir da concepção particular de sincretismo aqui utilizada, que não haja polarizações antagônicas entre as matrizes religiosas que atuam no Paraguai; mas que a interpenetração e a ressignificação recíprocas de símbolos e significados na convergência de crenças contribuem com a emergência de uma identidade religiosa hibridizada, na qual não há subsunção ou hierarquização de cosmovisões e práticas religiosas, apenas reconhecimento dos diversos caminhos pelos quais se pode alcançar o sagrado.

No Paraguai, apesar de se dizerem católicos, muitos indivíduos se dedicavam - e se dedicam concomitantemente à prática de outras religiões, tais como o espiritismo de orientação kardecista, o candomblé e a umbanda; demonstrando a existência de uma junção de sentidos e significados religiosos diversos naquele país. Não obstante, a religião assumida é a católica, ainda que frequentem templos evangélicos, centros espíritas e terreiros de umbanda e candomblé (NASCIMENTO, 2012).

Essa momentânea transferência de fé religiosa de uma matriz para outra não quer dizer a assunção de uma crença em detrimento de outra, como afirma Prandi (1995, p. 11) quando analisa o sincretismo, “essa reposição não apaga, contudo, a identidade primária da religião tributária, que pode, numa situação de mudança, refazer suas combinações originais, ou chegar a outras." Nesse sentido, Robbins (2014, p. 24) assevera, baseado em pesquisas realizadas no Brasil e na Papua Nova Guiné, que "as pessoas acham possível pertencer a uma religião e também participar de rituais fora dela", em razão de que o ritual de uma religião poderia preencher uma lacuna existente na matriz simbólico-ontológica de outra.

A presença e o trânsito de indivíduos de matrizes religiosas diversas é constante em espaços considerados sagrados e de culto específico de determinadas divindades; bem como é patente a participação desses indivíduos nas cerimônias e rituais que têm lugar nesses espaços, não ocorrem somente no Paraguai, como atestam os trabalhos de Fantinel (2014), Ferreti (1995), Guimarães (2009), Prandi (1995), Robbins (2014), Romão (2018), Serra (1995; 2009), dentre tantos outros. No Brasil, a Lavagem do Bonfim incorpora vários ritos africanos à festa católica, tendo como ponto de convergência a elaboração de afinidades, por parte dos adeptos do candomblé, entre Oxalá e o Senhor do Bonfim (SERRA, 2009).

Esse pluralismo de crenças, suas imbricações e convergências é visto por Prandi (1997, p. 76 apud SIQUEIRA, 2002, p. 178), quando discute a existência de um mercado religioso, como um "pluralismo religioso, em que a religião não é mais a religião. Não há mais uma única fonte de transcendência capaz de dar sentido à vida e à sociedade como um todo". O mesmo pluralismo, aponta

1 A propósito da discussão sobre os vários sentidos e interpretações a respeito do sincretismo religioso, veja Droogers (1989, p. 7-25); Ferreti (1998, p. 182-198); e Montero (2003, p. 112-121). 
Siqueira (2002), é nominado de formas diferentes por outros autores, que utilizam termos como campo religioso ampliado; religião difusa; religiosidade ou identidade religiosa flexível-flutuante, nebulosa místico-esotérica e crédulos difusos e muitos outros na tentativa de explicar a dinâmica dialética das transformações religiosas na contemporaneidade.

Nessa perspectiva, o pluralismo religioso identificado por Paiva (2004), quando estuda brasileiros adeptos de novas religiões japonesas, identifica também a junção de elementos religiosos diversos na constituição da identidade religiosa dos indivíduos. Apesar de haver, no caso da investigação de Paiva (2004, p. 24, grifo no original), a troca de religião, os novos adeptos das matrizes religiosas japonesas no Brasil conservam, e fazem questão de ressaltar, partes dos sistemas de valores da matriz religiosa anterior, como observa uma das entrevistadas que assevera ter conservado tudo, "porque o ensinamento é o mesmo, mas mudou a visão: pensa em ser útil ao próximo e não simplesmente em amar a Deus e ao próximo, aqueles Dez Mandamentos, que as pessoas ouvem e não praticam." E continua, "Deixei umas coisas de lado e vieram outras coisas novas: elas são as mesmas coisas, só que eu ajo de forma diferente. " A ressignificação é patente na fala da entrevistada, simbolizando uma tomada de posição específica e pessoal a partir da nova matriz religiosa à qual se vincula.

Para Siqueira (2002, p. 178), em que pese o fato dessas novas formas de expressão religiosa pluralizada remeterem, em um primeiro momento, à “superficialidade, mercado, inconsistência, há a possibilidade de que a existência de grupos ou de novas religiosidades possa ser pensada como indicativa de uma nova consciência religiosa, como fenômeno emergente que problematiza princípios básicos da modernidade.”

$\mathrm{O}$ artigo aqui apresentado originou-se de trabalho de campo de cunho etnográfico realizado nas cidades paraguaias de Pedro Juan Caballero e Assunção, tendo como objetivo entender a dinâmica da formação identitária entre centro (Assunção) e periferia (no caso a cidade fronteiriça de Pedro Juan Caballero). Ainda que o foco da pesquisa etnográfica não fosse a religiosidade e seus símbolos, essas categorias estiveram bastante presentes na verbalização dos interlocutores quanto às suas percepções sobre sua identidade cultural e as maneiras de entenderem a si mesmos.

Entrevistas semiestruturadas e livres, trabalho de campo e observação participante foram as estratégias metodológicas utilizadas para a captação de dados. Os depoimentos dos interlocutores sobre as questões religiosas foram coletados em diferentes contextos (trabalho, festas, reuniões), emergindo de maneira espontânea quando da resposta às indagações sobre as identidades socioculturais do homem paraguaio. Nessas respostas, a religiosidade e o uso dos símbolos para representá-la ficaram patentes, bem como está presente na dinâmica cultural o sincretismo religioso, no qual se misturam religiões ameríndias, o catolicismo, o protestantismo, o kardecismo, o candomblé e a umbanda.

\section{ORIGENS DA RELIGIOSIDADE PARAGUAIA}

O conceito de religiosidade pode ser entendido, grosso modo, como as manifestações e práticas simbólicas, ritualísticas e devocionais às quais se dedicam os indivíduos que comungam e professam um determinado conjunto de princípios orientados por uma religião e seu sistema de crenças. Geralmente, esse sistema de crenças é construído tendo como pressupostos ontológicos uma cosmogênese mítica e dogmática que caracteriza e retroalimenta as premissas fundantes da religião à qual se devotam cultos, adorações e sacrifícios. A religiosidade expressa, em quaisquer de suas manifestações, uma transcendência, ou ao menos uma tentativa, do homem em relação à matéria física que o caracteriza e o determina, representa uma ligação com o sagrado e uma busca de sentido para a existência terrena, cuja incerteza de origem e destino final inquietam a humanidade desde sempre (ELIADE, 1991;1992).

No Paraguai, de acordo Brezzo (2010), Carvalho (1987), Dorado (s/d) e Velázquez (2011), a influência dos colonizadores foi decisiva na constituição da religiosidade paraguaia que atualmente se percebe naquele país. Mas antes da chegada dos colonizadores a região hoje conhecida como Paraguai 
já tinha milhares de habitantes, detentores de sua própria cosmogonia, representada pelos seus mitos fundadores, pelos seus deuses, xamãs e heróis, simbolizados e contatados através de suas danças, coreografias e formas outras de devoção (NIMUENDAJU, 1987; SCHADEN, 1966).

Como marco cronológico, Brezzo (2010) e Velázquez (2011) acreditam que o processo de sincretização religioso se deu com a chegada dos franciscanos e dos jesuítas no território sul-americano. Os primeiros que aportaram naquela região foram os franciscanos, em 1575; 13 anos depois (1588) foi a vez dos jesuítas. Essas ordens religiosas empreenderam ao longo dos anos a sua catequização "salvadora", buscando pacificar os indígenas e "proteger" suas almas do domínio do mal. Esse choque de cosmogonias, por assim dizer, resultou na configuração religiosa que se tem hoje no Paraguai, configuração esta que guarda estreitas e indissociáveis relações com os esforços envidados por franciscanos e jesuítas no sentido de instaurar sua soberania não pelo uso da força, mas pelas estratégias de convencimento (MELIÀ, 1997).

Melià (1997) acredita que a conversão dos Guaranis por parte dos franciscanos e jesuítas foi facilitada devido ao fato de haver estreita vinculação entre o "modo de ser guarani" e a simbolização da dimensão religiosa cristã. Nessa teoria, a aceitação da conversão e o fato de irem residir nas missões guardam relação com a semelhança entre a organização social dos Guarani e a vida nas missões, ambas indissociavelmente vinculadas à lógica religiosa. No entanto, para Sposito (2012, p. 230), esse processo não aconteceu de forma harmoniosa, isso porque ainda que inseridos em um espaço de dominação reducional, os conflitos não são de todo evitáveis, "não se pode afastar as tensões, as negociações e as rebeliões ocorridas dos aldeados em relação aos padres. Uma luta que se dava não somente no mundo real, mas no universo simbólico, numa medição de forças entre crenças e deuses".

Sposito (2012) e Paris (1997), dentre outros historiadores, acreditam que a religiosidade originária do povo guarani sofreu influências negativas com a chegada dos colonizadores europeus, visto que na interpretação deles as práticas de caráter religioso relativas às esferas do sagrado adotadas pelos indígenas foram condenadas ao esquecimento, sendo substituídas pelas premissas simbólico-religiosas do conquistador. Em verdade, todos os povos sob a rubrica de indígenas, bem como a matriz cultural que os particularizava, foram impactados significativamente, entre os séculos XVI e XVII, pela colonização ibérica ocorrida na América; mas o processo desencadeado afetou de maneira mais contundente e singular os Guarani (MELIÁ, NAGEL, 1995; MONTEIRO, 1992).

Nesse contexto, no que diz respeito às práticas indígenas que buscavam alcançar o sagrado, aquilo que aos colonizadores europeus se afigurava como uma falsa religião, ou mesmo ausência desta, foram suprimidas dando lugar à "nueva religión llegada con la conquista, la del obispo y su clero, la de los misioneros, franciscanos y jesuitas, sobre todo, y la del colono [...]”. Essa nova religião assumia, frente àquela que substituía, um caráter triplamente danoso: "de menosprecio (que conlleva ignorancia), de desprecio (que provoca rechazo) y de oposición (que requiere destrucción). Muy raramente se da un reconocimiento del otro que sería, sin embargo, el fundamento de una conversión verdaderamente Cristiana." (MELIÁ, 1997, p. 161).

Paris (1997) afirma que para serem catequizadas as populações originárias tinham de ser encontradas, isto é, era necessário ir ao seu encontro, o que demandava longas viagens pelos rios Paraguai e Paraná, já que a travessia pelas florestas intocadas e de vegetação extremamente densa era uma alternativa inexequível. $\mathrm{O}$ autor assevera haver certa facilidade no trato com indígenas que habitavam esses territórios remotos, dado seu temperamento pacífico; o que era extremamente vantajoso ao projeto de dominação instalado.

Segundo o autor, a educação dada aos nativos paraguaios pelos jesuítas "foi feita nos mesmos princípios que costumavam usar, os quais usam e usarão em todos os povos e em todos os lugares". Seu objetivo, para este pesquisador, "é a renúncia de todo julgamento pessoal, toda a iniciativa, uma submissão cega ao superior". Boehmer, afirma que a moral dos Guarani foi negativamente afetada pelas premissas do ideário jesuítico "A ávida moral dos Guarani se enriqueceu muito pouco sob a disciplina dos padres." 
Essa influência exerceu forte mudança no espírito dos Guarani, transformando-os em católicos devotos e supersticiosos, crendo testemunhar milagres em todos os lugares e desenvolvendo um gosto pela autoflagelação que visava à expiação de pecados imaginados. Dessa maneira "Aprenderam a obedecer e foram ligados aos bons padres (que cuidaram tão bem deles) com uma gratidão de filhos que, apesar de não ser profunda, era de qualquer forma muito tenaz." (BOEHMER apud PARIS 1997, p. 29-30).

No entanto, outras interpretações são aduzidas às defendidas por Meliá (1997), Paris (1997) e Boehmer no que tange às influências exercidas pelos jesuítas na composição da religiosidade Guarani. Para autores como Schaden (1982) e Chamorro (2008), não existiu a assimilação da religiosidade do indígena guarani em favor da religião do colonizador europeu. Para Schaden, a religião de todos os grupos tribais que vivem no Paraguai não é cristã, mas guarani, opinião compartilhada por Chamorro (2008).

O que se tem, então, é uma maneira sui generis dos povos indígenas, dentre eles os Guarani, de elaborar estratégias que permitiram - e permitem ainda - a eles circular com certa desenvoltura tanto no universo religioso de sua matriz cultural quanto no universo religioso da sociedade envolvente. Desse modo, conforme as elucubrações de Brandão (1990) e Chamorro (2008), o que emana dessa inter-relação é um aparente hibridismo religioso que encerra em sua essência elementos que se aglutinam e funcionam de forma dialética na realidade sociocultural experienciada pelos indivíduos. Esse sincretismo, na interpretação de Brandão (1990, p. 81), não pode ser entendido como o subproduto dessa relação como "sistemas religiosos em si mesmo, postos em relação, os que intercambiam elementos de troca e que, como resultado, produzem amálgamas peculiares ou subsistemas religiosos."

Brandão (1990, p. 82) defende que o que existe é a elaboração de novas junções “de e entre sistemas integrados de símbolos e significados religiosos. Processos de subordinação e domínio também entre os símbolos e seus valores; recriações lógicas e possibilidades de recriação de rearranjos dentro de uma mesma religião, ou na fronteira entre ela e uma outra." Assim, o autor assevera que no caso Guarani o que acontece, teoricamente, é uma espécie de jogo de relações, em que resistência e subordinação configurariam polos aparentemente antagônicos; mais que na verdade seriam o mote da interação entre o índio e a sociedade envolvente no que concerne à questão religiosa.

Então, se a integridade religiosa da tribo é resguardada, ainda que em um primeiro momento, ao preço de transferir para sua margem os princípios valorativos postos em ação pela dinâmica ritual de outras religiões, em um segundo momento, observa Brandão (1990, p. 82), "ainda articulada e dominantemente a religião tribal reordena seu próprio logos para pensar-se a si mesma através do que integra de uma outra religião, cujo sistema dissolve em sua própria lógica: em e como seu sistema religioso." A propósito da questão das influências religiosas legadas ao Guarani pelos padres jesuítas, Clastles (1978) não acredita, como o faz Egon Schaden, que houvesse a possibilidade de retorno à condição original cessada a influência religiosa do colonizador.

As concepções de Schaden (1982) Brandão (1990) e Chamorro (2008) posicionam-se contra os lugares comuns de algumas análises científicas que concebem o contato dos indígenas com os colonizadores sempre a partir de categorias como perda e resistência, que acabam por traduzir "oposições binárias entre vencedores e vencidos, dominantes e dominados, e deixam para os povos nativos apenas dois papéis, os de vítimas de aniquilação ou de mártires da conservação de sua cultura. Num e noutro caso, o destino é um silencioso ou heroico desaparecimento" (POMPA, 2003, p. 22).

Pompa (2003) acredita que fica cada vez mais distante, se é que algum pesquisador ainda acredite nele, a aceitação do paradigma de "identidades puras originárias" dos indígenas, identidades estas que não teriam sido conspurcadas pelo "projeto civilizatório" dos religiosos "brancos" e conquistadores. Para a autora em tela, existe uma "lógica mestiça", locução cunhada por Gruzinski (2001), na qual a oposição

2 Assimilação aqui é compreendida como o processo pelo qual "um grupo étnico se incorpora noutro", perdendo suas peculiaridades socioculturais e sua identificação étnica anterior, o que resulta em alterações tendo como pressupostos dois eixos: um cultural (aculturação) e outro sociológico (mobilidade social) (OLIVEIRA, 1976, apud DAL POZ, 2003, p. 179). 
sistemática dos povos indígenas face às orientações compulsórias que lhes foram impingidas não ocorre "apenas em termos de revolta, mas também de estratégias de mediação, de adaptação e reformulação de identidades, de construção de novas formações sociais e culturais [...]” (POMPA, 2003, p. 22).

Pompa (2003) não nega o massacre e o esbulho impostos aos povos originários pelos colonizadores; nem tampouco nega as influências negativas e a lógica de dominação colonialista europeia que plasmaram a realidade sociocultural e psíquica dos povos submetidos, como bem demonstrou Memmi (2007), Métraux (1950), Quijano (1995), Said (1989; 1995; 1996), Aimé (2006 [1955]) e Fanon (2007 [1961]), apenas não acredita que as análises sobre o tema devam ser operacionalizadas sempre pelo viés interpretativo que relegam os povos indígenas a ocuparem papéis de vítimas e/ou de mártires.

Para Pompa (2003), o encontro colonial ensejou, também, mas não só, a oportunidade de construção de sentidos sobre o "Outro", construção esta instrumentalizada dialeticamente pela reconstrução das alteridades envolvidas na negociação das linguagens simbólicas que se inter-relacionam e se interpenetram no devir sociocultural.

Mas é forçoso reconhecer que houve, sim, perdas no que diz respeito a aspectos culturais das religiões guarani quando em contato com os colonizadores, não obstante todas essas religiões terem conservado, como assevera Clastles (1978, p. 11), "uma tradição religiosa original com o maior empenho, porque nela, e só nela, entraram ao mesmo tempo a razão e o meio de resistirem ao mundo dos brancos." Exemplo dessas perdas pode ser percebido no desaparecimento do Nimongarai, a mais relevante das festas apapocuva-guarani. De acordo com Clastles (1978, p. 35), "Nimuendaju assistiu às derradeiras".

As perdas relativas à realização do Nimongarai (Festa de primícias) não se restringem apenas à esfera de comemoração em razão da colheita dos primeiros frutos, posto que a festa encerrava em si significados político-religiosos que objetivavam chancelar alianças políticas e reforçar laços sociais, Clastles (1978). Carlos Fausto (2005), em Se Deus fosse jaguar: canibalismo e cristianismo entre os Guarani (séculos XVI-XX), mostra como o "contato com o cristianismo missionário e a experiência colonial conduziram a uma crescente negação do canibalismo como fundamento do poder xamânico e da reprodução social", processo de "desjaguarização" das divindades guarani que atuou no sentido de provocar perdas à cosmogênese ameríndia, ressaltando o fato de que o sincretismo ocorreu paralelamente à extinção progressiva de práticas e rituais religiosos associados à compreensão metafísica dos Guarani sobre a constituição do mundo.

A teorização de Fausto (2005), calcada em ampla análise dos autores clássicos que se dedicaram a estudar os Guarani (Egon Schaden; Curt Nimuendaju; León Cadogan), diverge da tese de que, no que tange ao aspecto sincrético entre metafísica cristã e metafísica ameríndia, os Guarani se mantiveram - no campo religioso - inalterados, não sofrendo as influências que a alteridade do colonizador europeu impingia à coletividade dos povos originais à época.

A questão religiosa está imbricada no modo de ser paraguaio, nas suas manifestações de caráter identitário, tanto as identidades autoatribuídas quanto às nacionais. Suas tradições religiosas, oriundas da cosmogonia indígena guarani ou as tributárias do colonizador europeu, deixam claro a importância dos símbolos culturais erigidos para expressar sua devoção e fé, sejam elas católicas, protestantes ou de outra matriz qualquer.

\subsection{SÍMBOLOS E TRADIÇÃO NO PARAGUAI: FACES E INTERFACES DA RELIGIOSIDADE}

A imagem de Nossa Senhora de Caacupé é bem pequena, medindo pouco mais de cinquenta centímetros. Seus pés apoiam-se sobre um pequeno globo e suas vestes trazem uma faixa branca de seda. O Santuário de Caacupé é um centro nacional de peregrinações, atraindo todos os anos milhares de peregrinos que chegam para demonstrar seu amor e gratidão a Nossa Senhora de Caacupé, também conhecida como a Mãe de todos, a Virgem dos Milagres e a Virgem Azul do Paraguai (NICKSON, 1993; SIGRIST, 1993). 
Segundo Boidin (2007), a origem de Nossa Senhora de Caacupê no Paraguai vincula-se a uma lenda corrente naquele país, na qual se conta que no final do século XVI um índio converso, que tinha por profissão a arte da escultura, passeava sobre uma montanha quando foi atacado e perseguido por indígenas da etnia Mbayae. Na sua fuga, conseguiu safar-se dos seus perseguidores ao se esconder detrás de um tronco de árvore muito grossa. Enquanto esperava que seus inimigos se dispersassem de todo, rogava à Nossa Senhora que o protegesse e o livrasse da morte. Depois de algum tempo, seus perseguidores desistiram da busca e foram embora, deixando para trás um escultor extremamente agradecido à Nossa Senhora pelo milagre recebido, já que acreditava que sua vida tinha sido poupada graças à intervenção da Santa. Em agradecimento esculpiu - com um pedaço do tronco que o havia acolhido - uma imagem da Virgem. Ainda conforme Boidin (2007), o lago Tapaicuá em 1603 transbordou submergindo completamente o vale de Pirayú. A enchente levou consigo tudo que estava em seu caminho, inclusive a imagem de Nossa Senhora. Quando as águas baixaram, a lenda conta que milagrosamente apareceu a imagem que o índio esculpira: Nossa Senhora de Caacupé.

A religiosidade paraguaia se manifesta de várias maneiras, mas a mais conhecida manifestação de fé e devoção no Paraguai pode ser testemunhada por ocasião da festa de Caacupê, que tem seu ápice no dia 8 de dezembro. A celebração é também realizada pelos paraguaios que se encontram fora do país, ou por motivo de trabalho esporádico ou devido à imigração definitiva. Desse modo, a festa se reproduz em Dourados/MS, Nova Andradina/MS, em Campo Grande/MS, em São Paulo/SP e em outras partes do Brasil onde haja paraguaios. Em decorrência da festa, as famílias se reúnem para rezar missas, para apreciar os pratos típicos peculiares da cultura paraguaia bem como outras manifestações culturais tais como a música e a dança.

Nessas conjunturas, emergem com mais vivacidade os símbolos culturais, materiais e imateriais, acionados para representar a devoção dos fiéis, tais como terços, cruzes e os chamados ex-votos ${ }^{3}$, que são trazidos pelos peregrinos e deixados nas salas de milagres (SIGRIST, 1993). Os símbolos são expressão da linguagem religiosa que perpassa pelos contextos em que categorias como fé e devoção estão presentes, constituindo parte significativa da gramática simbólica na qual a fé e a devoção se originam, se estruturam e atuam na vida social e psíquica dos indivíduos, o que ocorre devido ao fato de que todas "as culturas e todos os povos tiveram e têm uma expressão religiosa" (CROATO, 2010, p. 9).

Sobre o pensamento simbólico, Eliade (1991) acredita que ele não está presente somente no universo lúdico próprio das crianças, ou da imaginação dos poetas e mesmo daqueles considerados insanos, ele é uma característica intrínseca do ser humano, antecede a linguagem e a estrutura discursiva. Isso porque o símbolo desvela alguns aspectos aparentemente incognoscíveis da realidade, aspectos esses de difícil apreensão por outras formas de conhecimento. Assim, "As imagens, os símbolos, os mitos, não são criações irresponsáveis da psique; elas respondem a uma necessidade e preenchem uma função: revelar as mais secretas modalidades do ser. Por isso, o seu estudo nos permite conhecer o homem, o homem simplesmente" (ELIADE, 1991, p. 8-9).

A lógica simbólica transcende a especificidade da matéria, transformando objetivos inanimados em símbolos que denotam uma relação insuspeitada, até então, entre o mundo físico e o mundo extrafísico. No livro de Gêneses existe uma passagem que ilustra bem a transformação de objeto material em símbolo sagrado. No texto bíblico, Jacó ${ }^{4}$ viaja à casa de seu tio Labão, irmão de sua mãe, quando cai a noite e cansado da caminhada, deita-se no chão e toma uma pedra como travesseiro, dormindo logo em seguida. E ele tem um sonho no qual vê uma escada pela qual descem e sobem anjos, servindo, a escada, como uma forma de comunicação entre o céu e a terra. No sonho de Jacó, Deus lhe transmite uma mensagem. Quando acorda, pega a pedra que lhe serviu de travesseiro e jura sobre ela, derramando azeite sobre a pedra. A pedra deixa a

3 O ex-voto é o nome que se dá aos objetos (joias, esculturas, fotos, etc.) ofertados por devotos aos santos de sua devoção, geralmente em agradecimento a um milagre alcançado pelo fiel e ao qual ele atribui à entidade que cultua. Cf.: Silva (1981).

4 Cf.: Bíblia Sagrada (2009, p. 48, Gênesis 28: 10-22). 
esfera do mundo inanimado e passa a ser um símbolo da manifestação prolongada do sagrado (hierofania), deixando, assim, de ser algo comum para tornar-se algum incomum (ELIADE, 2010).

Sobre a relevância e função dos símbolos religiosos, Pedroso (2003, p. 107) afirma que "El movimiento religioso popular se acentúa en el dramatismo de los símbolos. Los signos simbólicos representativos encierran en si la representación formal de la realidad ausente." Para o autor em questão, esse sistema simbólico é retroalimentado na esfera da reciprocidade, visto que concomitantemente e animados pelas mesmas condicionantes "reciben [os símbolos] la dignidad o sacralidad de sus representados."; tornando-se, nesse sentido, pontos visíveis de uma realidade invisível (PEDROSO, 2003, p. 108).

Contudo, Pedroso (2003) esclarece que a devoção voltada às imagens e aos demais signos representativos não se trata de fetichismo ou simples idolatria ${ }^{5}$; visto que esses signos configuram-se - no contexto religioso - como mecanismos simbólicos que permitem o acesso dos fiéis ao espaço do sagrado, representado nos símbolos e nas imagens, tal como à da Virgem de Caacupê. O povo sabe perfeitamente que a imagem que cultuam da Virgem de Caacupê é esculpida em madeira, que recebeu pintura e ornamentos, e não lhes interessa conhecer sua origem material. E sabe também, continua Pedroso (2003, p. 108-109), "que esta pieza de madera, se transformó en um objeto sagrado, por su Representación. [...] La religiosidad tiene sus sistema de símbolos. Sin ellos no habría religión alguna entre los hombres constituídos de cuerpo y alma, y vivientes en sociedad."

Assim, de acordo com Pedroso (2003, p. 73), o símbolo religioso, no caso a imagem da santa, constitui-se em una condición sine qua non, imprescindible a la religiosidad, posto é ele quem intermedeia a relação entre o divino e o sagrado nos contextos religiosos. O divino, aqui, é entendido como o entende Pedroso, como significando o próprio Deus, e o sagrado se refere às pessoas e/ou coisas que tenham relação com Deus (2003, p. 72), sendo o símbolo em suas várias representações a ponte que permite a comunicação entre o homem e seus deuses. Essa ponte seria, em tese, a solução ao problema central da religião aludido por Leach (1983, p. 59, grifo nosso), isto é restaurar alguma espécie de ponte entre o Homem e Deus".

Como assinala Turner (2005, p. 52) "Os símbolos produzem ação, e os símbolos dominantes tendem a se tornar focos de interação. Os grupos mobilizam-se ao seu redor, cultuam-nos, desempenham outras atividades simbólicas perto deles, e acrescentam-lhes outros objetos simbólicos". Portanto, o símbolo transcende sua materialidade constituindo-se, como observou Leach (1983, p. 160) em "uma representação material de uma ideia abstrata". Assim, o símbolo, revestido de magia se insere no sobrenatural e traz desses confins inefáveis as respostas a perguntas não formuladas, a desejos não revelados cujos conteúdos são sempre prenhes de incertezas, de desvãos, de obscuridade e do desespero existencial tão peculiar à condição humana.

No entanto, os símbolos religiosos não devem ser confundidos com a religião em si mesma, já que, como alertava Rubem Alves: o religioso não seria uma qualidade inerente ao símbolo ou à prática como tal, mas estaria relacionado com as suas funções [...] A função religiosa é uma integração entre biografia e história, indivíduo e cosmos [...]; produzindo, assim, [...] uma integração emocionalmente satisfatória entre o indivíduo e a totalidade. (ALVES, 1982, p. 112-113)

Esse sistema de símbolos elabora e organiza suas propriedades com o objetivo de manipular e direcionar os tipos de representações mentais que se podem ter acerca dessas propriedades e, por conseguinte, dos seus portadores (BOURDIEU, 2006). Nesse sentido, os signos são repositórios de significado que, por sua vez, como observa Geertz (1989, p. 93) "só podem ser 'armazenados' através de símbolos: uma cruz, um crescente ou uma serpente de plumas.” Para Geertz, esses conjuntos de símbolos religiosos que se expressam na dramaticidade dos rituais e nos relatos míticos tendem a assumir, para aqueles que com eles se identificam, "tudo o que se conhece sobre a forma como é o mundo, a qualidade de vida emocional que ele suporta, e a maneira como deve comportar-se quem está nele". Os símbolos, assim pensados, realizariam a síntese do ethos de um povo, posto que dariam "o tom, o caráter e a qualidade da sua vida, seu estilo moral e estético, e

5 A propósito do fenômeno das idolatrias no contexto da colonização ibérica, veja: Vainhas (1991). 
sua disposição é a atitude subjacente em relação a ele mesmo e ao seu mundo que a vida reflete" (GEERTZ, 1989, p. 83).

O autor em questão atribui importância vital aos símbolos no tocante à organização dos indivíduos inseridos em determinado sistema social. Para ele, os símbolos significantes - sistematicamente organizados - são a expressão dos padrões culturais das sociedades e, portanto, sem eles, "o comportamento do homem seria virtualmente ingovernável, um simples caos de atos sem sentido e de explosões emocionais, e sua experiência não teria qualquer forma.". Desse modo, no entendimento de Geertz (1989, p. 33), a totalidade de tais padrões está organizada, ou acumulada, na cultura dos povos; não sendo um mero "[...] ornamento da existência humana, mas uma condição essencial para ela - a principal base de sua especificidade".

A festa realizada em homenagem à Virgem de Caacupé reúne as pessoas não somente pela adoração à santa; mas também para participar de um evento onde estaria presente a oportunidade de entretenimento e encontro. Se os mais velhos se aproximam do púlpito improvisado e se apinham e se acotovelam ao redor do altar onde está erigido o presépio, os mais jovens, em sua maioria, ficam a distância entretendo-se em conversas com os amigos, ao sabor do tereré ou de outra bebida qualquer. $\mathrm{O}$ tom das conversas gira em torno dos interesses tão peculiares da idade: futebol, garotas e episódios de suas vidas particulares que querem partilhar com outros naquele momento. Então, enquanto para alguns a festa se reveste de caráter sagrado, para outros ela enseja apenas o encontro, o entretenimento, a paquera. A festa pode ser entendida como uma espécie de ritual, visto que tanto uma quanto o outro possibilitam aos seus participantes um certo distanciamento da vida ordinária, rotineira, cotidiana (NASCIMENTO, 2012).

Na interpretação de Del Priore (2000) a festa propicia a afirmação, ou reafirmação, dos inúmeros laços sociais que unem os indivíduos em determinada sociedade, laços como os de solidariedade, amizade e companheirismo; ensejando, também, a oportunidade de indivíduos marcarem suas especificidades, diferenças e características identitárias. Nesse sentido, a festa em homenagem à Virgem de Caacupê enseja e oportuniza aos paraguaios o exercício de manutenção de reforço dos laços mencionados por Del Priore.

Segundo Durkheim, toda festa - ainda que essencialmente de caráter laico - carrega em si algumas características de cerimonial religioso. $\mathrm{O}$ autor entende a festa como um instrumento social que tem por objetivo primordial a aproximação entre os indivíduos; visando, com isso, a movimentação das massas, a transgressão às normas e o surgimento de um certo "estado de efervescência, às vezes mesmo de delírio, que não é desprovido de parentesco com o estado religioso". Desse modo, é possível observar "tanto num caso como no outro, as mesmas manifestações: gritos, cantos, música, movimentos violentos, danças, procura de excitantes que elevem o nível vital etc.” (DURKHEIM, 1989, p. 547).

Essa "efervescência" atinge seu ápice, segundo Durkheim (1989, p. 372), nas festividades religiosas, "nos dias de festa, a vida religiosa atinge grau de excepcional intensidade". Para o autor em causa, o estado de efervescência "[...] muda as condições da atividade psíquica. As energias vitais são superexcitadas, as paixões mais vivas, as sensações mais fortes.” (1989, p. 603)

Durkheim demonstra as dificuldades que a festa - enquanto categoria passível de análise apresenta ao pesquisador interessado em sua dinâmica. Aqui, o entretenimento de cunho recreativo, bem como suas manifestações aparentes, adquirem particular relevância para a religião, cotejando-os à dramaticidade de suas representações e trazendo à baila a dificuldade de se perceber com precisão os limites existentes entre distração pública e ritualismo religioso.

No caso da festa de Caacupê realizada em 2012, o aparente "desprendimento" em relação ao caráter litúrgico do evento, não era visto somente nos jovens, muitos adultos - ainda que aparentemente compenetrados - tratavam de assuntos totalmente divergentes da esfera religiosa. A festa, que na ocasião se deu em espaço público, favorecia o oferecimento e a venda de bebidas e alimentos acondicionados em isopores; camisetas de times de futebol, dentre muitos outros. Assim, o espaço da festa ganha outros sentidos que não somente o religioso, mas se insere também na esfera econômica e lúdica (NASCIMENTO, 2012). 
Vê-se que as injunções impostas pela lógica capitalista atravessam, mas não esvaziam, a esfera do sagrado, a ela se agrega na intenção de ocupar, também, um pedaço do espaço simbólico detido pela Santa. A influência é patente quando se percebe que a maioria das lojas do comércio abre suas portas no dia da comemoração em homenagem à santa, anteriormente considerado como feriado sagrado. Quando inquiridos do motivo de abrir as portas em dia tradicionalmente reputado como sagrado, alguns comerciantes disseram que não podiam perder a oportunidade de realizar uma boa venda, visto a cidade estar, nesse período, repleta de turistas de várias regiões e nacionalidades (NASCIMENTO, 2012).

Aqui, a inter-relação entre as esferas do sagrado e do profano, bem como sua intersecção e capilaridades, dão a tônica da festa em homenagem a Santa de Caacupé, conferindo ao evento a complexidade própria das manifestações socioculturais que o homem engendra, cultiva e transforma inconscientemente. Assim, as categorias em questão, sagrado e profano, guardam em si uma intrínseca relação ambivalente de oposição e complementação, em que ambas se subentendem dinâmica e dialeticamente.

Em um mundo em constante transformação - de valores, de costumes e visões de mundo ${ }^{6}$ - é de fácil compreensão essa aparente indiferença à liturgia que a comemoração enseja. Assim, a tradição de "guardar" o dia da Santa é preterida em favor de uma lógica econômica onde o objetivo é o lucro. Ou como já havia assinalado Weber $(1999$, p. 5): "Claro que el propio estilo de vida religiosamente condicionado está profundamente afectado por los factores económicos y políticos que actúan en el interior de determinados limites geográficos, políticos, sociales y nacionales".

Bourdieu (2006), partindo do conceito de capital simbólico, que é, segundo sua teoria, um processo que se dá no devir da história, acredita que as perspectivas religiosas adquirem sua legitimidade em múltiplas situações. Portanto, a festa não perde sua importância diante dos fiéis, apenas alguns dos seus aspectos sofrem algumas mudanças devido ao caráter dinâmico das sociedades. Parafraseando Weber, Bourdieu assevera que toda a construção social e histórica a respeito dos deuses segue a inconstância e volubilidade da história de seus seguidores e asseclas, dado o fato de tal produção simbólica ter sua origem no reflexo do contexto social em que é gestada.

Apesar de historicamente tido como um país católico, muitos paraguaios se identificam adeptos de outras religiões, tais como a protestante (menonitas, batistas e pentecostais). Em que pese o fato de o catolicismo ser a religião mais popular, não é a religião oficial desde a promulgação da constituição paraguaia de 1992; que permitiu a prática de religião ou crença de qualquer tipo (NASCIMENTO, 2012).

Conforme os relatos de Blaustein e Flanz (1993), apesar do teor democrático de que se reveste o texto constitucional, em 1994, no mês de agosto para ser exato, a Associação dos Pastores Evangélicos, com sede no Paraguai, solicitou ao Congresso o reconhecimento dos direitos legais de seus pastores, pois acreditavam estar sendo preteridos em relação aos padres católicos. A alegação tinha por base o repasse de recursos e demais auxílios à Igreja Católica em desproporção aos concedidos aos grupos protestantes e outras entidades religiosas; fato que configurava, aos olhos da Associação dos Pastores Evangélicos, um claro desrespeito e desprestígio à sua instituição e as demais localizadas naquele país - ainda mais quando este se declarava laico em sua constituição; como mostra San Juan (1993) “A liberdade de religião, culto, e ideologia, é reconhecido sem quaisquer outras restrições que as estabelecidas nesta Constituição e na lei. O Estado não tem religião oficial (Art. 24)”.

Em Assunção também pode ser facilmente percebida a presença de outras religiões que não a católica ou às de matiz protestante. Funciona à rua Dr. Gaspar Rodrigues de Francia esquina com 14 de mayo, no 493 - San Lorenzo Paraguay - o Templo Xango Ilé Oxum Ketu O. As atividades religiosas nesse espaço atendem às três linhas: Candomblé, Umbanda e Kimbanda. O templo fica em uma região afastada do grande centro comercial da cidade. Aqui, presume-se que a localização do templo em lugar afastado advém da estratégia de "proteger", por assim dizer, os adeptos e praticantes dessas

6 A respeito do conceito de "visão de mundo", adota-se, aqui, à interpretação dada por Geertz (1989, p. 93), “A visão de mundo [...] é um quadro que elabora [determinado povo] das coisas como elas são na simples realidade, seu conceito de natureza, de si mesmo, da sociedade." 
religiões da curiosidade alheia, dado o fato de tais religiões não serem "vista com bons olhos"; além de ser uma religião marginalizada e praticada por pobres, na sua maioria (NASCIMENTO, 2012).

Apesar de muitas pessoas se assumirem católicas praticantes, o que se observa no Paraguai é a prática de outras religiões, sendo que a maioria não vê problemas em frequentar ora o centro espírita, ora o terreiro e ora os templos pentecostais. "Dios está en todo lugar, hijo, pero principalmente aquí [apontando com o dedo a direção do coração]", disse um interlocutor paraguaio quando inquirido do porquê era adepto de várias crenças religiosas. Outros alegaram como justificativa certa curiosidade em relação a outras formas de se alcançar o sagrado, ou ainda o descontentamento com algumas partes da doutrina da religião da qual eram devotos [Diário de Campo, 2012).

Segundo Borgoño (1995), na América Latina o sincretismo religioso tem sido uma das mais fortes expressões de disputa entre diversos grupos sociais. Contudo, o fenômeno do sincretismo não é estanque, não está engessado às suas formas constituintes; encontra-se em constante mutação, sofrendo as influências da dinâmica cultural da sociedade que o gerou e alimentou - e que, portanto, dita regras de ação, reação, transformação, adequação e readequação a serem seguidas.

\section{IDENTIDADE NACIONAL E RELIGIOSIDADE}

A religiosidade no Paraguai esta intrinsecamente associada à identidade nacional daquele povo; dado o fato de sua formação cultural, sociológica e psicológica estar indissociavelmente vinculada às influências religiosas legadas a eles pelos franciscanos e jesuítas. Reflexo dessa afirmação pode ser percebido na preponderância da religião católica no país, na devoção e crença de que são destinatários os santos católicos, ao culto aos símbolos que particularizam o cristianismo.

A Virgem de Caacupê se constitui no maior símbolo religioso do Paraguai, posto que a crença depositada em seus poderes supostamente milagrosos arrasta milhares de pessoas às ruas em várias regiões do país, ensejando a realização de procissões quilométricas e posterior aglomeração de fiéis, tanto na cidade de Caacupê quanto em outras cidades do território paraguaio; na intenção de pagar promessas e alcançar milagres.

A cidade de Caacupé pode ser considerada como a capital espiritual do Paraguai. Capital do departamento (estado) de Cordillera, Caacupé tem pouco mais de 21 mil habitantes, população que triplica no mês de dezembro, quando as festividades em homenagem à Virgem de Caacupé, padroeira do Paraguai, atraem milhares de devotos à cidade. Em relação a esta última, tem-se que se originou de um pequeno povoado fundado por volta de 1600 por guaranis convertidos ao cristianismo. As histórias referentes à origem da cidade são repletas de lendas, tais como a do índio José, que teria esculpido a primeira imagem da Virgem como agradecimento a um milagre (PEDROSO, 2003).

Documentos datados de 1765 já se referiam à vila serrana com o nome de Ka'a Kupé, que em guarani, significa "erva atrás dos montes". Cinco anos mais tarde, em 1770, foi inaugurado o primeiro templo em homenagem à Virgem, substituído no século XX pela atual Basílica de Caacupé, atualmente o maior atrativo turístico da cidade. A Basílica é uma das maiores do mundo, visitada pelo Papa João Paulo II em 1988. Todos os anos, nas semanas que antecedem a festa da Virgem (08/12), ocorrem atividades especiais no templo (PEDROSO, 2003).

Outras formas de expressão religiosa no Paraguai podem ser identificadas por ocasião da Semana Santa, do Dia dos Mortos e do Dia da Cruz; datas sagradas onde são lembradas a morte de Cristo e a morte de entes queridos. Em relação às cerimônias fúnebres realizadas por ocasião do Dia dos Mortos e do Dia da Cruz, Pedroso (2003) acredita que estas são manifestações baseadas em princípios filosófico-religiosos que, por sua vez, são tributários de variadas fontes culturais. Segundo ele, La cosmovisión sobre este horizonte [as cerimônias fúnebres] es sumamente amplia, y lo constituyen cultos normativos establecidos tradicionalmente. Para o autor, tais cultos são estabelecidos pela enseñanza de la Iglesia y la corriente de prácticas folklóricas, impregnadas 
del cristianismo, con resabios tal vez paganos. O autor assinala que a crença popular é muito rica e diversificada no que diz respeito às manifestações e atitudes que originam todo o sistema elaborado para cultuar os mortos, sendo extremamente difícil visualizar uma linha divisória entre as duas correntes mencionadas.

O autor em questão acredita que a dificuldade se encontra no fato de a igreja no período colonial, bem como aquelas que a sucederam, terem influenciado o povo com diversas práticas póstumas, que se associaram àquelas legadas pela tradição familiar de cunho popular. Portanto, assinala Pedroso (2003, p. 56). "Se puede afirmar que muchas prácticas de difuntos hoy son folklóricas, habiendo sido en su origen prácticas eclesiales."

O autor se pergunta ¿Cómo se originó el novenario de ánimas, la práctica del luto, la cruz del difunto, etc.? Respondendo a questão que ele mesmo formula, acredita que Son de origen paralitúrgicas eclesiásticas que para ahondar la vida religiosa de las familias fueron practicadas con el sello de las obras de misericordia: enterrar a los muertos y la doctrina fundamental Cristiana: la verdad de la otra vida. (PEDROSO, 2003, p. 56-57).

Em relação ao Dia da Cruz, Pedroso acredita que a cruz, enquanto símbolo, cumpre la representación del enterrado bajo su sombra sagrada. Ella ocupa la misión y ell lugar del que ha ido, y da testimonio de la sobrevivência de ultratumba.. Se o dono da tumba foi uma pessoa bondosa, a cruz é venerada e visitada pelo público; se foi uma pessoa considerada cruel, o lugar é tido como assombrado por espíritos malignos, nesse caso, são providenciadas missas (PEDROSO, 2003, p. 60-61). O exposto nos parágrafos anteriores ilustra a importância da religião na constituição da identidade cultural do povo paraguaio.

Outro ponto interessante em relação ao sentimento de nacionalidade do paraguaio pode ser percebido no uso que esse povo faz dos seus símbolos pátrios. Um desses símbolos é exibido à exaustão quando da realização da Festa de Caacupê: a bandeira paraguaia. Esta pode ser vista tremulando as centenas nas mãos de adolescentes, adultos e até idosos; ou decorando a janela dos apartamentos e casas; afixadas nos capôs dos carros ou, ainda, figurando como parte da indumentária, em forma de camiseta, dos transeuntes, principalmente os mais jovens. Às vezes são confeccionadas bandeiras gigantescas para serem carregadas pelos devotos durante a caminhada. Aqui, o símbolo tende a reforçar o sentimento de pertencimento, de união em torno de um outro símbolo, este de cunho religioso, representado pela imagem da Santa de Caacupê.

Desse modo, é perfeitamente compreensível a atitude do governo paraguaio em dar mais importância às manifestações religiosas de cunho católico do que às das outras religiões praticadas naquele país. Ou seja, a Virgem de Caacupê constitui-se em um símbolo religioso por excelência do Paraguai, representa através de suas manifestações a expressão de uma identidade nacional paraguaia, posto que tem o poder simbólico de identificar o povo com sua nação. Portanto, de acordo com Sobral (2006, p. 2): E, como ocorre em todas as formas de identificação, pertencer-se a uma nação implica partilhar referências a um passado comum - uma memória - e acreditar que esse coletivo possui características próprias: uma identidade."

Tanto em Pedro Juan Caballero quanto em Assunção, e em diversas regiões do país, as imagens da santa de Caacupê se fazem presentes em distintos espaços: no interior das lojas podem ser vistas penduradas às paredes, ou ainda em pequenos altares erigidos para acomodar a Santa quando esta é construída de madeira ou resina. No interior de algumas casas a imagem da santa também está presente. Quando perguntados do porquê de a imagem estar sempre presente, respondem que é pra dar proteção" (NASCIMENTO, 2012)

A Catedral de Caacupê é o destino final das procissões por conta do seu caráter de lugar, ou espaço, do sagrado. Esse lugar sagrado pode ser considerado uma fronteira metafórica, visto constituir uma abertura, na qual o "recinto sagrado, o mundo profano é transcendido" (ELIADE, 1992, p. 19). Aqui, guardadas as devidas proporções, percebe-se o legado do cristianismo no cotidiano dos para- 
guaios, bem como foram moldadas historicamente sua identidade nacional, ou seja, a identidade de um povo construída a partir de referenciais de cunho religioso e de valores notadamente reputados como cristãos, tais como a solidariedade, a justiça, a retidão; valores tão presentes e verbalizados quando indagados a respeito da constituição do ser paraguaio.

Nesse contexto, somente a autofragelação não está presente na comemoração feita em homenagem à Santa de Caacupê nos dias de hoje. A assistência às missas; a participação em procissões e até mesmo as penitências são uma constante no período em que a festa é realizada, como se pode depreender das imagens acima. É obvio que os contextos históricos são diferentes, mas os sentidos que emanam de sua práxis, em maior ou menor grau e respeitando suas particularidades históricas, ainda guardam muito de sua origem.

A adoração aos símbolos religiosos no Paraguai, bem como em outros lugares em que essa prática é realizada, tem a ver, também, salvo melhor interpretação, com uma busca das origens primordiais do homem, algo como a procura do primeiro ventre, não aquele concebido de carne e osso, mas aquele oriundo do sobrenatural, do mundo mágico e espiritual.

A existência humana não se restringe somente à manutenção do corpo físico por meio dos alimentos, ela depende, ainda, do universo simbólico e suas determinações. O homem não vive só de pão, mas também de símbolos, posto que sem a existência destes a ordem, enquanto ordenamento do mundo, estaria condenada à extinção; o mesmo pode ser dito a respeito do sentido para a vida, ou ainda a vontade de viver (ALVES, 1981). Desse modo, é inegável a influência da religião na composição da identidade, ou das identidades, do povo paraguaio, como já assinalado por muitos autores de nacionalidade paraguaia, como afirma Carvalho (1987, p. 31): "Varios autores compatriotas han visto la efectiva influencia religiosa cristiana durante el largo proceso de consistencia colectiva".

A identidade nacional está indissociavelmente vinculada ao conceito de nação e aos símbolos de que esta se utiliza para coadunar a massa populacional em torno de um discurso identitário comum. A convivência em sociedade tende a permitir a assimilação dos grupos sociais em torno das identidades que esta mesma sociedade engendra. Assim, tem-se que as identidades são produtos sociais, são criações; portanto, são passíveis de toda espécie de fragilidade, de distorções, suscetibilidades, simplificações e interpretações por parte dos indivíduos. Portanto, apesar de compartilharem os mesmos símbolos, isso não quer dizer que não haja conflitos, ressentimentos, ódios velados e dissensões entre os membros de uma mesma sociedade, ou de uma mesma nação.

Os símbolos podem ter ou não materialidade. Como símbolos materiais podem ser considerados, como já mencionado: a bandeira nacional de um país, seus brasões, seus monumentos históricos. Os símbolos imateriais podem ser identificados nos aspectos da história de um povo, nas narrativas folclóricas, no culto aos heróis de guerra; enfim, podem ser percebidos nas entrelinhas dos discursos nacionalistas que permeiam as sociedades complexas, ou melhor dizendo, modernas. Assim, o discurso nacional poderia ser interpretado - como o faz Anderson 1983; Hobsbawm em 1984 -; como um instrumento que engendra e mantém uma nação enquanto uma comunidade organizada, ou imaginada, como conceitua Anderson (1983).

Elias (1997, p. 16) adverte que a identidade nacional, ou habitus nacional, como prefere nominar, não é incrustada de uma única vez no imaginário social; mas, sim, intrinsecamente relacionado às transformações peculiares por que passam a formação das nações. Portanto, a identidade nacional é produto da história de um povo e dela tributário. Contudo, sofre mutações as mais diversas ao longo do tempo; ou seja, assume um caráter dinâmico e situacional que visa, dentre outras coisas, dar sentido à vida social e cultural de um determinado povo em um determinado tempo e espaço - sendo também transmitida pela via da tradição, categoria que é, segundo os autores citados, mutável e maleável. Nas palavras de Rutherford (1990, p. 19-20 apud WOODWARD, 2009, p. 19): "a identidade marca o encontro de nosso passado com as relações sociais, culturais e econômicas nas quais vivemos agora [...]".

Os argumentos apresentados acima vão de encontro à tese de Latour (2008), que acredita que aparentemente - não existam mais os laços sociais que sustentam a noção de um "nós", pois "parece 
que estamos ligados por vínculos que não são vínculos sociais comuns.”. Em termos de noções de identidade nacional, os símbolos em questão ainda são e estão muito presentes no imaginário social dos povos; do contrário, as nações já teriam se esfacelado vítimas de toda sorte de teorias apocalípticas brilhantemente elaboradas por alguns teóricos sociais.

Anderson (1983); Hobsbawm (1984) e Bourdieu (2006), acreditam que tal categoria - a identidade nacional - assume diferentes aspectos no devir histórico, sempre relacionado aos interesses e ideologias dos grupos dominantes em voga no interior dos Estados Nações. Ou seja, os símbolos nacionais, tanto os materiais quanto os imateriais, podem ser manipulados de acordo com os interesses das instâncias de poder, assim, uma tradição pode ser reinventada, agregando ou subtraindo elementos, para reforçar - ou esgarçar - práticas culturais que representem, ou não, importância dentro do conjunto simbólico de uma nação. Dessa maneira, o passado de um povo pode ser reconstruído, esquecido e lembrado para elaborar e/ou reafirmar uma identidade.

A respeito do caráter maleável das tradições, Hobsbawm (1984, p. 9) comenta que "Muitas vezes, 'tradições' que parecem ou são consideradas antigas são bastante recentes, quando não são inventadas". Anderson (1983, p. 14-15), discutindo a existência das nações enquanto comunidades imaginadas, entendia que estas se diferenciam não por sua aparente falsidade ou autenticidade, mas pelo estilo em que estas nações são imaginadas; isto é, o que lhes dá credibilidade enquanto nações é maneira como são tratados, dispostos e incutidos no imaginário social de um povo, os elementos simbólicos que possibilitam a construção e manutenção de uma comunidade nacional. Portanto, para os autores em questão, o que importa é a forma como são inventadas e, quanto menos perceptível essa "invenção", mais forte e coesa se torna uma nação. No tocante às "tradições inventadas", cabe aqui o comentário de Hobsbawm (1984, p. 9), para quem a locução "tradição inventada" é utilizada "num sentido amplo, mas nunca indefinido. Inclui tanto as "tradições" realmente inventadas, construídas e formalmente institucionalizadas, quanto as que surgiram de maneira mais difícil de localizar num período limitado e determinado de tempo [...]”.

O autor divide, dessa forma, as tradições inventadas em duas vertentes: às que foram "inventadas" de forma "real", ou seja, para atender a uma necessidade social, cultural e simbólica de um determinado país em um determinado período histórico, e às que são "inventadas" pelos modismos tão comuns às esferas da comunicação, do entretenimento e da literatura. Ainda que o social e o simbólico sejam frutos de processos diferentes, Woodward (2009, p. 14) adverte que "cada um deles é necessário para a construção e a manutenção das identidades. A marcação simbólica é o meio pelo qual damos sentido a práticas e as relações sociais, definindo, por exemplo, quem é excluído e quem é incluído".

As identidades nacionais se inserem nesse conjunto de representações acerca do caráter de um povo. No caso do povo paraguaio, como de tantos outros povos, a identidade nacional está intrinsecamente relacionada aos aspectos históricos que o particularizam. Assim, é forçoso reconhecer que a análise das identidades; bem como seus pressupostos primordiais de estruturação devem levar em consideração mais as condições e processos políticos e históricos da formação em si, do que o seu conteúdo cultural, independentemente de sua configuração (BARTH, 1998 [1969]).

Castells (1999) discorda de Barth quanto ao caráter de coadjuvante da cultura no contexto da formação das identidades. Para Castells, a cultura tem particular relevância nessa análise, visto que a identidade pode também ser entendida como um "processo de construção de significado com base em um atributo cultural, ainda um conjunto de atributos culturais inter-relacionados, os quais prevalecem sobre outras fontes de significado" (1999, p. 22). Barth reconhece a importância que a cultura exerce na constituição das identidades, independente de fronteiras, quaisquer sejam as formas como estas se apresentam "a cultura é 'distributiva', isto é, que ela não conhece fronteiras nacionais e pode se deslocar transformando-se em correntes de contatos interculturais aos quais é exposta" (LASK, apud BARTH, 2000, p. 18). Contudo, para ele, o critério de definição de uma identidade étnica é o da autoatribuição, como já mencionado, se uma pessoa diz que é A, então ela é A, e deve ser tratada 
como A - ainda que - aparentemente - esteja inserida em uma cultura predominantemente considerada como B. (BARTH, 2000, p. 33).

\section{CONSIDERAÇÕES FINAIS}

Desse modo, a identidade nacional e religiosa do povo paraguaio pode ser localizada tanto no seu devir histórico enquanto nação, quanto nas manifestações culturais acionadas para representar tais identidades. Isto é, pode ser localizada por meio de sua herança cultural indígena, pelas influências do período colonial, através da influência religiosa legada pelos franciscanos e jesuítas; ou, ainda, no culto e adoração à Virgem de Caacupê, na constante rememoração dos propalados feitos heroicos de seus heróis de guerra, e na construção de uma identidade paraguaia essencializada e indissociavelmente vinculada aos símbolos materiais e imateriais erigidos e constantemente rememorados.

Contudo, as identidades não são inamovíveis, fixas e inquebrantáveis. Sofrem injunções advindas das circunstâncias sociais em que são gestadas, daí se manifestarem, por vezes, fragmentadas e dissociadas em sua dinâmica. Optar por esta ou aquela prática religiosa, ou por mais de uma ao mesmo tempo, pode ser interpretado como um jogo de xadrez onde as identidades assumem o papel das peças em jogo, e a realidade seria o próprio tabuleiro em que as peças se adequam da melhor maneira que lhes seja possível diante das circunstâncias e imposições do devir frenético da vida cotidiana.

No que diz respeito ao campo religioso, tal expressão de cunho identitário acha-se pulverizada em sua substância estrutural; todavia, em seu aspecto comunicativo/discursivo encontra-se plenamente coesa. As pessoas se dizem católicas praticantes, mas acorrem a outras religiões em busca da realização de seus desejos. Mas a que se atribuiria esse ecletismo? Talvez a explicação esteja na derrocada do catolicismo no mundo atual, o que deixaria seus antigos adeptos à mercê de outras opções religiosas como o espiritismo, o candomblé, a umbanda e tantas outras em oferta hoje em dia. Mas as pessoas não abandonam sua fé de uma hora para outra; há um processo que as impele a buscar outras formas de alcançar o sagrado, mas esse processo é lento, o que leva a experimentação de várias práticas religiosas até a escolha daquela que melhor lhes aprouver.

O sincretismo religioso, e as leituras que dele emanam em razão das dissensões acadêmicas a respeito do conceito, se expressa de diversas maneiras no tecido social, permeando as sociedades de ontem e de hoje e conformando dialeticamente sua estrutura. No jogo semântico das definições, redefinições e ressignificações, em que às vezes há mais aproximação de um lado e afastamento de outro, o sincretismo se apresenta sob várias nuances, nem sempre perceptíveis dada sua carga simbólica, mas sempre presente na realidade das relações e inter-relações entre os indivíduos, seja lá qual for o nome que se lhe atribua.

Portanto, o culto a Nossa Senhora Virgem de Caacupé, santa padroeira do Paraguai, nos leva a pensar a respeito dos componentes socioculturais que as práticas religiosas congregam em si e em seu entorno, componentes estes tributários do universo simbólico e do campo das representações. A fé e a devoção publicamente manifestas por meio da liturgia religiosa a que o povo paraguaio se dedica, dão testemunho da força de sua crença na Virgem de Caacupé; e tal força tem sua materialidade no santuário construído em sua homenagem. Neste santuário são encenados e reproduzidos os ritos católicos oriundos da fé na Santa. No contexto religioso que enseja tais práticas rituais, diversas características da vida em coletividade estão inclusas. Um desses aspectos é o caráter festivo, em que as representações ritualísticas são constituídas por meio de danças, músicas e a produção e consumo de alimentos considerados tradicionais. 


\section{REFERÊNCIAS}

AIMÉ, C. Discursos sobre el colonialismo. Madrid: Ediciones Akal, 2006 [1955].

ALVES, R. A empresa da cura divina: Um fenómeno religioso? In: VALE, E.; QUEIROZ, J. J. et. al. (Org.). A cultura do povo. São Paulo: Universidade Católica de São. 1982. p. 111-117.

ALVES, R. O que é religião. Coleção Primeiros Passos. São Paulo: Editora Brasiliense, 1981.

ANDERSON, B. Imagined communities: reflections on the origin and spread of nationalism. London; New York: VERSO, 1983.

BARTH, F. O Guru, o iniciador e outras variações antropológicas. Rio de Janeiro: Ed. Contra Capa, 2000.

BARTH, F. Grupos étnicos e suas fronteiras. In: POUTIGNAT, P.; STREIFF-FENART, J. Teorias da etnicidade; seguido de grupos étnicos e suas fronteiras. São Paulo: Ed. UNESP, 1998.

BÍBLIA SAGRADA. Tradução para a Língua Portuguesa de João Ferreira de Almeida 4a Edição Revista e Corrigida. Barueri/SP: Sociedade Bíblica do Brasil.

BLAUSTEIN, A. P.; FLANZ, G. H. Constitutions of the countries of the World. New York: Oceana Publications, 1993. BOIDIN, B. Aide au developpement et santé comme droit humain. Èthique et écinomique, v. 5, n. 1, p. 121.2007.

BORGOÑO, M. A. Pensamiento católico y sincretismo religios latinoamericano: hacia una historia de nuestra comprensión de lo religioso en las últimas décadas. In: II Congreso Chileno de Antropología. Colegio de Antropólogos de Chile A. G, Valdivia, 1995. Disponível em https:/www.aacademica.org/ii.congreso.chileno.de.antropologia/43.pdf Acesso em: 14 fev. 2019.

BOURDIEU, P. O poder simbólico. 9. ed. Rio de Janeiro: Bertrand Brasil, 2006.

BOURDIEU, P. Gênese e estrutura do campo religioso. In: Economia das trocas simbólicas. São Paulo: Perspectiva, 1976. p. 27-78.

BRANDÃO, C. R. Os Guarani: índios do Sul - religião, resistência e adaptação. Estudos Avançados. São Paulo, v. 4, n. 10, p. 53-90, 1990.

BREZZO, L. M. La historia y los historiadores. In: TELESCA, I. (Coord.). Historia del paraguay. Asunción-Paraguay: Taurus. 2010. p. 13-32.

CARVALHO, R. M. Raices, tiempo y memória: origen, formacion y caracter del ser paraguayo. Asunción: [s.n], 1997.

CASTELLS, M. A Sociedade em rede - a era da informação: economia, sociedade e cultura. São Paulo: Paz e Terra, 1999. v. 2.

CLASTLES, H. Terra sem mal: O profetismo tupi-guarani. São Paulo: Brasiliense, 1978.

CÉSAIRE, A. Discours sur le colonialisme. Paris: Quatrième édition, Editions PRÉSENCE AFRICAINE, [1955] 2006.

CHAMORRO, G. TERRA MADURA YVY ARAGUYJE: Fundamento da Palavra Guarani. Dourados: Editora UFGD, 2008.

CHEVALIER, J.; GHEERBRANT, A. Dicionário de símbolos: (mitos, sonhos, costumes, gestos, formas, figuras, cores, números). Rio de Janeiro: José Olympio, 2002.

CROATO, J. S. As linguagens da experiência: uma introdução à fenomenologia da religião. São Paulo: Paulinas, 2010. (Coleção religião e cultura) 
DAL POZ, J. A etnia como sistema: contato, fricção e identidade no Brasil indígena. Sociedade Cultura. v. 6, n. 2, 2003. p. 177- 188 .

DEL PRIORE, M. Festas e utopias no Brasil Colonial. São Paulo: Brasiliense, 2000.

DROOGERS, A. Syncretism: the problem of definition, the definition of the problem. In: GORT, J. et al. (Ed.). Dialogue and syncretism: an interdisciplinary approach. Amsterdam: William B. Eerdmans: Rodopi, 1989. p. 7-25

DORADO, A. G. La evangelización colonial en el presente de la cultura paraguaya. Quadernos de Pastoral Social, Assunção, n. 7, [s. d.].

DURKHEIM, É. As formas elementares de vida religiosa - o sistema totêmico na Austrália. Tradução de Joaquim Pereira Neto. São Paulo: Ed. Paulinas, 1989.

ELIADE, M. História das crenças e das ideias religiosas I - da idade da Pedra aos mistérios de Elêusis. Rio de Janeiro: Zahar, 2010.

ELIADE, M. O sagrado e o profano: a essência das religiões. São Paulo: Martins Fontes, 1992.

ELIADE, M. Imagens e símbolos. São Paulo: Martins Fontes, 1991.

ELIAS, N. Os alemães: a luta pelo poder e a evolução do habitus nos séculos XIX e XX. Rio de Janeiro: Jorge Zahar, 1997.

EVANS-PRITCHARD, E. E. Bruxaria, oráculos e magia entre os Azande. Rio de Janeiro: Zahar, 2005 [1937].

EVANS-PRITCHARD, E. E. Nuer religion. London: Oxford University Press. 1956.

FANON, F. Los condenados de la tierra. Rosario - Santa Fé - Argentina: Kolectivo Editorial Ultimo Recurso. Título original: Les damnés de la terre (Traducción de Julieta Campos). 2007 [1961].

FANTINEL, C. “Oropa, rrança e Bahia": lavage de la Madeleine, uma folia mestiça. 2014. 116 f. Dissertação (Mestrado em Cultura e Sociedade) - Universidade Federal da Bahia. Instituto Humanidades Artes e Ciências Milton Santos, Salvador, 2014.

FAUSTO, C. Se Deus fosse jaguar: canibalismo e cristianismo entre os Guarani (séculos XVI-XX). Mana, Rio de Janeiro v. 11, n. 2, p. 385-418, 2005.

FERRETI, S. Sincretismo afro-brasileiro e resistência cultura. Horizontes Antropológicos, Porto Alegre, ano 4, n. 8, p. 182-198, jun. 1998.

FRAZER, J. G. The golden bough: a study of magic and religion. Temple of Earth Publishing, 1890.

GEERTZ, C. A interpretação das culturas. Rio de Janeiro: LTC, 1989.

GRUZINSKI, S. O pensamento mestiço. São Paulo: Companhia das Letras, 2001.

GUIMARÃES, R. Sincretismos religiosos brasileiros. São Paulo: Cosac, 2009.

HOBSBAWM, E. Introdução: a invenção das tradições. In: HOBSBAWM, E. \& RANGER, T. (Org.). A invenção das tradições. Rio de Janeiro: Paz e Terra, 1984. p. 9-23.

LATOUR, B. Reensamblar lo social. Una introducción a la teoría del actor-red. Manantial, Buenos Aires: 2008.

LEACH, E. Cabelo mágico. In: Da MATTA, R. (Org). Edmund Leach. São Paulo: Ática, 1983, p. 139-169. (Coleção grandes cientistas sociais; 38 ).

LEACH, E. O gênesis enquanto um mito. In: DaMATTA, R. (Org). Edmund Leach. São Paulo: Ática, 1983 , p. 57-69. (Coleção grandes cientistas sociais; 38). 
LÉVI-STRAUSS, C. Antropologia estrutural. Rio de Janeiro: Tempo Brasileiro, 1989. [Cap. IX Magia e Religião 198-267].

MALINOWSKI, B. K. Magia, ciência e religião. Lisboa: Edições 70, 1988.

MARTINS, P. J. C. M.; COIMBRA, F. A. Catálogo da exposição. A suástica e suas variantes no norte de Portugal, desde a pré-história até a atualidade. Sociedade Martins Sarmento, 1997.

MARX, K. Crítica da filosofia do direito de Hegel. In: MARX, K. Sobre a religião. Lisboa: Edições 70, 1975, p.47-49.

MAUSS, M. Ensaio sobre a dádiva. Lisboa: Edições 70, 1988.

MELIÀ, B. El guarani conquistado y reducido: ensaios de etnohistoria. 4. ed., Assunción - Biblioteca Paraguaya de Antropologia - CEADUC/CEPAG, v. 5., 1997.

MELIÀ, B.; NAGEL, L. M. Guaranies y jesuítas em tiempo de las Misones: uma bibliografia didáctica. Santo Ângelo, RS: URI, Centro de Cultura Missioneira; Asunción: CEPAG, 1995.

MEMMI, A. O retrato do colonizado precedido pelo retrato do colonizador. [prefácio de Jean-Paul Sartre]. Rio de Janeiro: Civilização Brasileira. 2007 [1957].

MÉTRAUX, A. “Race et civilization”. In: LE COURRIER DE L'UNESCO. Volume III-No 6-7 Prix: 1 CHrs.-10 cents (U. S.).-6 penche (U. K.) JUILLET. AOUT. Page 8- 9. 1950.

MONTEIRO, J. M. Os Guarani e a história do Brasil Meridional. In: CARNEIRO DA CUNHA, M. (Org.). História dos índios no Brasil. São Paulo: Companhia das Letras: Fapesp: Secretaria Municipal de Cultura, 1992. p. $475-498$.

MONTERO, P. “O problema do sincretismo”. In: PEREZ, L. F.; QUEIROZ, R. C.; VARGAS, E. V. (Org.). Teoria e Sociedade (Revista dos Departamentos de Ciência Política e de Sociologia e Antropologia - UFMG), Belo Horizonte, número especial: Passagem de milênio e pluralismo religioso na sociedade brasileira, 2003, p. 112-121.

NASCIMENTO, V. A. “Yo soy paraguaio, chamigo”. Breve estudo sobre a identidade no Paraguai. 2012. 177 f. Dissertação (Mestrado em Antropologia) - Universidade Federal da Grande Dourados/UFGD, Dourados/MS, 2012.

NICKSON, A. Historical dictionary of Paraguay. Scarecrow Press; Edição: Revised, Enlarged, Subsequent, 1993 [Serie: Historical Dictionaries of the Americas (Livro 24)].

NIMUENDAJU, C. As lendas da criação e destruição do mundo como fundamentos da religião dos Apapocúva-Guarani. Curt Nimuendaju Unkel; tradução de Charlotte Emmerich; Eduardo B. Viveiros de Castro. São Paulo: HUCITEC; Editora da Universidade de São Paulo, 1987.

PAIVA, G. J. de. Identidade e pluralismo: identidade religiosa em adeptos brasileiros de novas religiões japonesas. Psic.: Teor. e Pesq., Brasília, v. 20, n. 1, p. 21-29, apr. 2004.

PARIS, E. A História Secreta dos Jesuítas. 21. ed. Trad. de Josef Sued (1987). Chick Publications. Disponível em: http://www.4shared.com/rar/RnIlrRQY/a_historia_secreta_dos_jesuita.html

PEDROSO, M. C. La religiosidad popular paraguaya y la identidad nacional.

Asunción-Paraguay: Imprenta Salesiana, 2003.

POMPA, C. Religião como Tradução. Missionários, Tupi e Tapuia no Brasil colonial. Bauru/São Paulo: EDUSC/ ANPOCS, 2003.

PRANDI, R. Prefácio. In. FERRETI, S. F. Repensando o sincretismo: estudo sobre a Casa das Minas. São Paulo: FAPEMA, 1995.

QUIJANO, A. Colonialidade do poder, eurocentrismo e América Latina. In: LANDER, E. (Org.). A Colonialidade do Saber - Eurocentrismo e Ciências Sociais - Perspectivas Latino-americanas. Buenos Aires: Clacso, 2005. 
ROBBINS, J. Pluralismo religioso e pluralismo de valores: ritual e a regulação da diversidade intercultural. Debates do NER, Porto Alegre, ano 15, n. 26, p. 15-41, jul./dez., 2014. Disponível em: https://seer.ufrgs.br/debatesdoner/article/ view/52034/32057 Acesso em: 2 jul. 2020.

ROMÃO, T. L. C. Sincretismo religioso como estratégia de sobrevivência transnacional e translacional: divindades africanas e santos católicos em tradução. Trab. linguist. apl., Campinas, v. 57, n. 1, p. 353-381, abr. 2018.

SAN JUAN, P. C. M. Constitutional reforms in Latin America promoting religious freedom. Puerto Rico: Rutherford Institute, 1993.

SAID, E. W. Orientalismo. O Oriente como invenção do Ocidente. São Paulo: Companhia das Letras, 1996 [1978].

SAID E. W. Cultura e imperialismo. São Paulo: Companhia das Letras, 1995.

SAID E. W. "Representing the Colonized: Anthropology’s Interlocutors”. Critical Inquiry, v. 15, n. 2, p. 205-225, 1989.

SCHADEN, E. A obra científica de Curt Nimuendajú. Suplemento Antropológico, Assunção, n. 1, v. $2,1966$.

SCHNEIDER, J. Discursos simbólicos e símbolos discursivos: considerações sobre a etnografia da identidade nacional. Mana [online], v. 10, n. 1, p. 97-129, 2004.

SERRA, O. Sincretismo e separação. Águas do rei. Petrópolis/RJ: Editora Vozes/Koinonia, 1995.

SERRA, O. Rumores da Festa: o sagrado e o profano na Bahia. Salvador: EDUFBA, 2009.

SIGRIST, M. A resistência cultural do povo paraguaio. Revista Arca, Campo Grande, n. 4, p. 56-60, 1993.

SILVA, M. A. M. da. Ex-votos e orantes no Brasil: leitura museológica. Rio de Janeiro: Museu Histórico Nacional, 1981.

SIQUEIRA, D. Novas religiosidades na capital do Brasil. Tempo Social; Rev. Sociol. USP, S. Paulo, v. 14, n. 1, p. 177197, maio de 2002.

SOBRAL, J. M. Memória e identidade nacional: considerações de carácter geral e o caso português. Working Papers, Universidade do Minho, Lisboa-Portugal, 2006.

SPOSITO, F. Santos, heróis ou demônios? Sobre as relações entre índios, jesuítas e colonizadores na América Meridional (São Paulo e Paraguai/Rio da Prata, séculos XVI-XVII. 2012. 342 f. Tese (Doutorado em História) - Universidade de São Paulo, São Paulo, 2012.

TURNER, V. Floresta de símbolos: aspectos do ritual Ndembu. Niterói/RJ: EdUFF, 2005.

TYLOR, E. B. Primitive culture. Researches into the development of mythology, philosophy,religion, language, art and custom. New York: Gordon Press, 1976.

VAINHAS, R. Colonialismo e idolatrias: cultura e resistência indígenas no mundo colonial ibérico. Rev. Bras.de Hist. S. Paulo v. 11 n 21 , p. 101-124 set. 90/fev. 91.

VELÁZQUEZ, R. E. Breve historia de la cultura en el Paraguay. Asunción-Paraguay: SERVILIBRO, 2011.

WEBER, M. Sociología de la religión. [S.I]: Ediciones elaleph.com. 1999. Disponível em: http://www.cholonautas. edu.pe/modulo/upload/Weber\%2020de\%201a\%20Religion.Pdf

WEBER, M. A ética protestante e o espírito do capitalismo. São Paulo: Pioneira, 1989.

WOODWARD, K. Identidade e diferença: uma introdução teórica e conceitual. In: SILVA, TOMAZ TADEU (Org. e trad.). Identidade e diferença. A perspectiva dos estudos culturais. Petrópolis, RJ: Vozes, 2009. p. 7-72. 


\begin{tabular}{|ll}
\hline Histórico & $\begin{array}{l}\text { Recebido em: 20/04/2019 } \\
\text { Revisão em: 23/07/2020 } \\
\text { Aceito em: 27/07/2020 }\end{array}$ \\
\hline Financiamento & Coordenação de Aperfeiçoamento de Pessoal de Nível Superior, CAPES, Brasil \\
$\begin{array}{c}\text { Aprovação, ética e } \\
\text { consentimento }\end{array}$ & Não se aplica \\
\hline
\end{tabular}

